\title{
Influence of some New Insecticides Mixtures against Cotton Bollworms and Their Side Effects on Associated Predators
}

\author{
Madeha E.H. El-Dewy and El-Zahi S. El-Zahi ${ }^{1}$
}

\begin{abstract}
Bollworms resistance to most registered insecticides has become a major obstacle to their successful chemical control with conventional insecticides. Therefore, field experiments were conducted at Sakha Agricultural Research Station in 2010 and 2011 cotton seasons to study the efficiency of four new mixtures (M) of insecticides, i.e. chloropyrifos + cypermethrin (M1), chloropyrifos + lufenuron (M2), flufenoxuron + alpha-cypermethrin (M3) and thiamethoxam + lambda-cyhalothrin (M4) and two conventional insecticides, chloropyrifos and alphacypermethrin, against cotton bollworms, Pectinophora gossypiella (Saund.) and Earias insulana (Boisd.). Also, their side effects on associated predators were studied. In 2010 season, M3 and alpha-cypermethrin in three successive sprays of each proved to be the superior recording 81.58 and $79.85 \%$ reduction in larval infestation, respectively. M4, M1 and chloropyrifos came in the second order without significant differences causing 77.38, 76.65 and $75.27 \%$ reduction, respectively. M2 was the least effective with reduction percentage of 74.15. The results of 2011 season showed the same trend of effect for all the tested compounds. According to their side-effects against associated predators, the tested toxicants could be arranged descendingly as follows, alpha-cypermethrin (81.00), M4 (77.96), M3 (76.68), M1 (69.02), M2 (66.07) and chloropyrifos $(64.28) \%$ reduction. The obtained results indicated that, the new tested mixtures of insecticides did not exhibit additional advantages in control of the cotton bollworms comparing to the conventional toxicants, where they showed approximately the same effectiveness against the pest and were harmful to the associated predators. Moreover, cross-resistance could be developed after repeated application of these mixtures.
\end{abstract}

\section{INTRODUCTION}

Cotton bollworms, Pectinophora gossypiella (Saund.) and Earias insulana (Boisd.) are considered of the most serious pests attacking cotton plants during flowering and later stages and cause about 30-40\% losses of seed cotton yield (Haque, 1991). Insect resistance to insecticides has become a major obstacle to successful chemical control with conventional insecticides. The evolution of insecticides resistance is governed by a complex of factors such as intense and repeated application of insecticides from the same chemical group or employs the same mode of action. To avoid the insect resistance development, there is need for different compounds with different modes of action (Aydin and Gürkan, 2006). Insecticides mixtures are usually applied in the field to enhance the spectrum of the control when multiple pests attack simultaneously. Mixtures are available as pre-mixes from pesticides companies or they are tank-mixed by farmers. Ideally, the insecticides with different modes of action are mixed on the assumption that they would complement the action of each other for killing the target pests. When two compounds are mixed, they can be potentiating, additive or antagonistic in an insect species. These effects can be varied on different insect species or strains depending upon their physiology and the mechanisms of resistance developed. The occurrence of insect resistance to an insecticide is mainly due to the action of enzymes which are either insensitive to the insecticide or able to degrade it to non-toxic metabolites. Because of their dissimilar mode of action, pyrethroids and organophosphates have commonly been mixed to control pests of cotton and other crops (Mushtaq, 2004). Insect growth regulators have a much slower mode of action than conventional insecticides, so their mixtures with conventional toxicants may give high initial and residual activities against the targeted pests; this procedure is very common to control the cotton leafworm and have taken several investigations (Ravi and Verma, 1997; El-Aswad, 2007). The aim of this work was to study the effectiveness of some new mixtures of insecticides against cotton bollworms, Pectinophora gossypiella and Earias insulana, comparing to conventional insecticides with respect to their side effects on associated predators.

\section{MATERIALS AND METHODS}

\subsection{Tested compounds:}

Trade names, formulations, active ingredients and concentrations of two conventional insecticides and four new mixtures are presented in Table (1).

\subsection{Experimental design:}

The experiments were carried out at the Farm of Sakha Agricultural Research Station, Kafr El-Sheikh, Egypt, where an area of $4200 \mathrm{~m}^{2}$ was selected to be sown with cotton seeds var. Giza 86 on April 15, 2010 and 2011 seasons and divided into plots (replications)

\footnotetext{
${ }^{1}$ Agricultural Res. Center, Plant Protection Res. Institute,

Giza, Egypt

Received June 18, 2013, Accepted September 9, 2013
} 
Table 1. Tested compounds against bollworms and their details

\begin{tabular}{lllc}
\hline Trade name & Formulation & \multicolumn{1}{c}{ Active ingredient } & Concentration (mg AI/L) \\
\hline Dursban $^{\mathrm{a}}$ & EC 48\% & Chloropyrifos 48\% & 2400 \\
Alphazid $^{\mathrm{b}}$ & EC 10\% & Alpha-cypermethrin 10\% & 125 \\
Chlorosan $^{\mathrm{b}}$ & EC 29\% & Chloropyrifos 24\% + cypermethrin 5\% & 1090 \\
Feroban $^{\mathrm{c}}$ & EC 50\% & Chloropyrifos 47.5\% + lufenuron 2.5\% & 2500 \\
Cygron $^{\mathrm{c}}$ & EC 10\% & Alpha-cypermethrin 7\% + flufenoxuron 3\% & 125 \\
Engeo $^{\mathrm{d}}$ & SC24.7\% & Thiamethoxam 14.1\% + lambda-cyhalothrin 10.6\% & 197.6
\end{tabular}

* Field recommended rate expressed in $\mathrm{mg} \mathrm{AI} / \mathrm{L}$

a.Dow AgroScience Co.

b.Kafr El-Ziat for Pesticides and Chemical Co.

c.National Co. for Agrochemical Production.

d.Syngenta Agrochemical Co.

each of $175 \mathrm{~m}^{2}$. Recommended agricultural practices were followed all through the season. Treatments were distributed in complete randomized block design with four replications. Four plots were taken as check without any insecticidal treatments. Each of the tested compounds was applied three times at two weeks intervals. The recommended field rate of each compound was diluted using irrigation water to give final volume of spray solution $476 \mathrm{~L} / \mathrm{ha}$; sprayed using a knapsack sprayer equipped with one nozzle $\left(\mathrm{CP}_{3}\right)$. Sprays were done on July 19, August 2 and August 17 for $1^{\text {st }}, 2^{\text {nd }}$ and $3^{\text {rd }}$ sprays, respectively in 2010 and 2011 cotton seasons.

\subsection{Representative samples of bollworms infestation:}

For assessing the infestation with cotton bollworms Pectinophora gossypiella (Saund.) and Earias insulana (Boisd.), 100 green bolls were picked up weekly at random from both diagonals of the inner square area of each plot according to the method of Shaaban and Radwan (1974). Inspections were started on July 19 and continued till September 1 of each season. The collected bolls were transmitted directly to the laboratory and inspected carefully to find out the infested bolls with pink and/or spiny bollworms. The equation of Henderson and Tilton (1955) was used to calculate the reduction percentages of infestation.

\subsection{Assessing the side effects of the tested compounds on some associated predators:}

The most prevailing predacious species in cotton fields, i.e. Chrysoperla carnea, Coccinella spp., Orius sp., Scymnus spp and true spiders were investigated according to Hafez technique (1960) to determine the side-effects of the tested compounds. From each plot, five cotton plants were chosen at random at the same dates of green bolls sampling and examined carefully using lens $(5 \mathrm{x})$ to count the number of studied predators/cotton plant. The reduction percentages were calculated using the equation of Henderson and Tilton

\section{Statistical analysis:}

Mean number of bollworms/100 green bolls and mean number of predators $/ 20$ cotton plants for each treatment were calculated and compared with one-way analysis of variance (ANOVA). Duncan's multiple range test was used to determine significant differences $(\mathrm{P}<0.05)$ between treatments by Costat system for windows, Costat Program (2006).

\section{RESULTS AND DISCUSSION}

Field experiments were conducted at Sakha Agricultural Research Station in 2010 and 2011 cotton seasons to study the efficiency of four new insecticides mixtures viz., chloropyrifos + cypermethrin (M1), chloropyrifos + lufenuron (M2), flufenoxuron + alphacypermethrin (M3) and thiamethoxam + lambdacyhalothrin (M4) and two conventional insecticides, chloropyrifos and alpha-cypermethrin, against cotton bollworms Pectinophora gossypiella (Saund.) and Earias insulana (Boisd.) as well as their side effects on common predators in cotton fields.

\subsection{Effectiveness of the tested compounds on cotton bollworms:}

The average numbers of bollworms larvae per 100 green bolls during 2010 and 2011 are presented in Table 2. It is quite clear that the infestation with both insects in the two seasons started with few numbers in the $1^{\text {st }}$ and $2^{\text {nd }}$ sprays and increased gradually till the end of each season. The average number of bollworms was higher in 2010 than in 2011. Comparing between the efficiency of the tested compounds against bollworms in 2010, data in Table (3) showed that M3 and alpha-cypermethrin in three successive sprays of each were the superior recording 81.58 and $79.85 \%$ reduction of larval populations. M4, M1 and chloropyrifos came in the second order causing 77.38, 76.65 and $75.27 \%$ reduction, respectively. M2 was the least effective with 74.15 reduction percentage. (1955). 
Table 2. Number of bollworms, Pectinophora gossypiella and Earias insulana, larvae/100 cotton green bolls as influenced by different treatments during 2010 and 2011 seasons Treatment

\begin{tabular}{|c|c|c|c|c|c|c|c|c|}
\hline \multirow[t]{4}{*}{ Treatment } & \multicolumn{7}{|c|}{ No. of bollworms larvae/100 green bolls pre- and after spray } & \multirow[t]{4}{*}{ Mean } \\
\hline & \multirow[t]{3}{*}{ Pre-spray } & \multicolumn{6}{|c|}{ After indicated sprays: } & \\
\hline & & \multicolumn{2}{|c|}{$\mathbf{1}^{\text {st }}$ spray } & \multicolumn{2}{|c|}{$2^{\text {nd }}$ spray } & \multicolumn{2}{|c|}{$3^{\text {rd }}$ spray } & \\
\hline & & 1 week & 2 weeks & 1 week & 2 weeks & 1 week & 2 weeks & \\
\hline & \multicolumn{8}{|c|}{ Season 2010} \\
\hline Chloropyrifos & 3.0 & 5.0 & 4.0 & 4.0 & 7.0 & 9.0 & 5.0 & $5.67 \mathrm{~b}$ \\
\hline Alpha-cypermethrin & 3.0 & 2.0 & 3.0 & 9.0 & 6.0 & 4.0 & 4.0 & $4.67 \mathrm{~b}$ \\
\hline Chlorosan (M1) & 3.0 & 3.0 & 2.0 & 7.0 & 5.0 & 11.0 & 11.0 & $6.50 \mathrm{~b}$ \\
\hline Feroban (M2) & 3.0 & 4.0 & 4.0 & 7.0 & 8.0 & 7.0 & 6.0 & $6.00 \mathrm{~b}$ \\
\hline Cygron (M3) & 4.0 & 3.0 & 4.0 & 8.0 & 7.0 & 7.0 & 6.0 & $5.83 \mathrm{~b}$ \\
\hline Engeo (M4) & 2.0 & 2.0 & 1.0 & 4.0 & 4.0 & 5.0 & 9.0 & $4.17 \mathrm{~b}$ \\
\hline \multirow[t]{2}{*}{ Check } & 3.0 & 10.0 & 17.0 & 21.0 & 25.0 & 55.0 & 44.0 & $28.67 \mathrm{a}$ \\
\hline & \multicolumn{8}{|c|}{ Season 2011} \\
\hline Chloropyrifos & 4.0 & 6.0 & 3.0 & 3.0 & 5.0 & 2.0 & 3.0 & $3.67 \mathrm{~b}$ \\
\hline Alpha-cypermethrin & 3.0 & 2.0 & 2.0 & 3.0 & 2.0 & 1.0 & 2.0 & $2.00 \mathrm{~b}$ \\
\hline Chlorosan (M1) & 3.0 & 5.0 & 4.0 & 2.0 & 3.0 & 4.0 & 2.0 & $3.33 \mathrm{~b}$ \\
\hline Feroban (M2) & 3.0 & 3.0 & 3.0 & 3.0 & 2.0 & 4.0 & 4.0 & $3.17 \mathrm{~b}$ \\
\hline Cygron (M3) & 5.0 & 4.0 & 3.0 & 2.0 & 3.0 & 4.0 & 4.0 & $3.33 \mathrm{~b}$ \\
\hline Engeo (M4) & 2.0 & 3.0 & 2.0 & 2.0 & 3.0 & 3.0 & 3.0 & $2.67 \mathrm{~b}$ \\
\hline Check & 2.0 & 8.0 & 10.2 & 14.0 & 11.0 & 25.0 & 21.0 & $14.83 \mathrm{a}$ \\
\hline
\end{tabular}

Means followed by the same letter are not significantly different using DMRT $(\mathrm{P}<0.05)$

Table 3. Reduction percentages of bollworms, Pectinophora gossypiella and Earias insulana, after application of various compounds in 2010 and 2011 seasons

\begin{tabular}{|c|c|c|c|c|c|c|c|}
\hline \multirow[t]{3}{*}{ Treatment } & \multicolumn{6}{|c|}{ \% reduction in bollworms larvae after indicated sprays: } & \multirow[t]{3}{*}{ Mean \pm SD } \\
\hline & \multicolumn{2}{|c|}{$1^{\text {st }}$ spray } & \multicolumn{2}{|c|}{$2^{\text {nd }}$ spray } & \multicolumn{2}{|c|}{$3^{\text {rd }}$ spray } & \\
\hline & 1 week & 2 weeks & 1 week & 2 weeks & 1 week & 2 weeks & \\
\hline & \multicolumn{7}{|c|}{2010 season } \\
\hline Chloropyrifos & 50.0 & 76.5 & 80.9 & 72.0 & 83.6 & 88.6 & $75.27 \pm 3.9$ \\
\hline Alpha-cypermethrin & 80.0 & 82.4 & 57.1 & 76.0 & 92.7 & 90.9 & $79.85 \pm 4.89$ \\
\hline Chlorosan (M1) & 70.0 & 88.2 & 66.7 & 80.0 & 80.0 & 75.0 & $76.65+4.97$ \\
\hline Feroban (M2) & 60.0 & 76.5 & 66.7 & 68.0 & 87.3 & 86.4 & $74.15 \pm 5.35$ \\
\hline Cygron (M3) & 77.5 & 81.3 & 71.4 & 79.0 & 90.5 & 89.8 & $81.58 \pm 5.89$ \\
\hline \multirow[t]{2}{*}{ Engeo (M4) } & 70.0 & 91.2 & 71.4 & 76.0 & 86.4 & 69.3 & $77.38 \pm 6.53$ \\
\hline & \multicolumn{7}{|c|}{2011 season } \\
\hline Chloropyrifos & 62.5 & 85.0 & 89.3 & 77.3 & 96.0 & 94.4 & $84.08 \pm 1.63$ \\
\hline Alpha-cypermethrin & 83.3 & 86.7 & 85.7 & 87.9 & 98.6 & 95.1 & $89.55+3.26$ \\
\hline Chlorosan (M1) & 58.3 & 73.3 & 90.5 & 81.8 & 89.3 & 95.1 & $81.30 \pm 2.45$ \\
\hline Feroban (M2) & 75.0 & 80.0 & 85.7 & 87.9 & 89.3 & 90.1 & $84.70 \pm 4.08$ \\
\hline Cygron (M3) & 80.0 & 88.0 & 94.3 & 89.1 & 92.0 & 94.1 & $89.60+1.63$ \\
\hline Engeo (M4) & 62.5 & 80.0 & 85.7 & 72.7 & 88.0 & 88.1 & $79.50 \pm 2.44$ \\
\hline \multirow{2}{*}{\multicolumn{4}{|c|}{$\begin{array}{l}\text { With respect to the percentage of reduction in } 2011 \text {, } \\
\text { data in Table (3) showed the same trend with all tested } \\
\text { compounds against bollworms infestation comparing to } \\
2010 \text { data, where the tested compounds could be } \\
\text { arranged descendingly according to their efficiency as } \\
\text { follows: M3 (89.60), alpha-cypermethrin (89.55), M2 }\end{array}$}} & \multicolumn{4}{|c|}{$\begin{array}{l}\text { (84.70), chloropyrifos (84.08), M1 (81.30) and } \mathrm{M} 4 \\
(79.50 \%) \text { reduction. }\end{array}$} \\
\hline & & & & \multicolumn{4}{|c|}{$\begin{array}{l}\text { Majority of previous studies indicated that protective } \\
\text { control programs using insecticidal treatments are } \\
\text { considered the most effective procedure for controlling } \\
\text { cotton bollworms mainly before the formation o } \\
\text { greenbolls. Watson et al. (1981) \& Bramhanker et al }\end{array}$} \\
\hline
\end{tabular}


(1990) reported that pyrethroids alternation with endosulfan, carbaryl and triazophos significantly provided the highest reduction in bollworms infestation. Pyrethroids were the most efficient in controlling bollworms and were superior to all other types of insecticides (Khurana and Verma, 1991; El-Hamaky et al., 1993; Sharaf, 2003; El-Basyouni, 2003). Moreover, the synthetic pyrethroids, lambda-cyhalothrin and deltamethrin, exhibited the greatest reduction in bollworms infestation comparing to the organophosphates, chloropyrifos and profenofos (Khan et al., 2007; Younis et al., 2007; Zidan et al., 2012). The insecticide mixture, Feroban, was the most potent against Spodoptera littoralis under the field conditions comparing to the other mixtures: Chlorosan, Cygron, Engeo and Kingbo (Abd El-Mageed and Shalaby, 2011). Accordingly, the results in Table (3) revealed that the new mixtures of insecticides are not preferable to be used to control the cotton bollworms, where the average reduction percentages of the tested mixtures approximately caused the same effectiveness comparing to alpha-cypermethrin and chloropyrifos. In addition to that, cross-resistance could be developed by using insecticides have the same mode of action in these mixtures.

\subsection{Side effect of the tested compounds against the common predators in cotton fields:}

The hazardous effects of the four new insecticides mixtures and the two conventional insecticides on the most abundant predators in cotton fields, i.e. Chrysoperla carnea, Coccinella spp., Scymnus spp., Orius sp. and true spiders were evaluated and the obtained results are presented in Tables 4 and 5. The results in Table 4 showed that, the average numbers of studied predators $/ 20$ cotton plants were significantly decreased after application of all tested compounds comparing to the check treatment. Insignificant differences were observed between the tested toxicants in this respect. Concerning the reduction percentages in studied predators, data presented in Table (5) cleared that alpha-cypermethrin was the most harmful recording $81.00 \%$ reduction, while chloropyrifos was the least harmful causing $64.28 \%$ reduction. Based on the general mean of reduction percentages, all treatments were destructive and reduced the population density of the studied predators. The descending order of the tested compounds in this respect was as follows: alphacypermethrin (81.01), M4 (77.96), M3 (76.68), M1 (69.02), M2 (66.07) and chloropyrifos (64.28) \% reduction.

The current results agreed with the findings of many investigators (Abbas and El-Deeb, 1993; Kostandy, 1995; Al-Beltagy et al., 1999; Salama et al., 2006). In the same direction, El-Dewy (2006) found that alphacypermethrin, chloropyrifos and carbaryl significantly reduced the population densities of Chrysoperla carnea, Coccinella spp., Scymnus spp. and true spiders. Also, Yousif-Khalil et al. (2008) mentioned that the organophosphate insecticide, chloropyrifos, caused the highest percentage of reduction in all investigated predators comparing to spinosad and methoxyfenozide. Moreover, El-Zahi and Arif (2011) reported that the conventional insecticides: lambda-cyhalothrin, alphacypermethrin, deltamethrin, methomyl, profenofos and chloropyrifos were ultimately toxic to the common predators in cotton fields recording $82.76-94.80 \%$ reduction comparing to thiamethoxam and imidacloprid which caused less than $50 \%$ reduction. In addition, Zidan et al. (2012) indicated that alpha-cypermethrin, lambda-cyhalothrin and profenofos were more toxic against predators than chloropyrifos and methomyl which induced moderate toxicity.

\section{Table 4. Mean number of common predators $/ 20$ cotton plants as influenced by application of various compounds during 2010 and 2011 seasons}

\begin{tabular}{|c|c|c|c|c|c|c|c|c|}
\hline \multirow[t]{3}{*}{ Treatment } & \multirow[t]{3}{*}{ Pre-spray } & \multicolumn{6}{|c|}{$\begin{array}{c}\text { Mean number of common predators/20 cotton plants after } \\
\text { indicated spray }\end{array}$} & \multirow[t]{3}{*}{ Mean } \\
\hline & & \multicolumn{2}{|c|}{$1^{\text {st }}$ spray } & \multicolumn{2}{|c|}{$2^{\text {nd }}$ spray } & \multicolumn{2}{|c|}{$3^{\text {rd }}$ spray } & \\
\hline & & 1 week & 2 weeks & 1 week & 2 weeks & 1 week & 2 weeks & \\
\hline Chloropyrifos & 45 & 15 & 9 & 8 & 5 & 12 & 6 & $9.17 \mathrm{~b}$ \\
\hline Alpha-cypermethrin & 48 & 14 & 4 & 0 & 0 & 11 & 3 & $5.33 \mathrm{~b}$ \\
\hline Chlorosan (M1) & 50 & 24 & 8 & 7 & 1 & 8 & 5 & $8.83 \mathrm{~b}$ \\
\hline Feroban (M2) & 53 & 7 & 11 & 11 & 8 & 15 & 9 & $10.33 \mathrm{~b}$ \\
\hline Cygron (M3) & 57 & 12 & 6 & 8 & 5 & 8 & 6 & $7.50 \mathrm{~b}$ \\
\hline Engeo (M4) & 44 & 5 & 2 & 4 & 2 & 13 & 9 & $5.83 \mathrm{~b}$ \\
\hline Check & 45 & 26 & 26 & 24 & 25 & 28 & 23 & $25.17 \mathrm{a}$ \\
\hline
\end{tabular}

Means followed by the same letter are not significantly different using DMRT $(\mathrm{P}<0.05)$ 
Table 5. Mean of reduction percentage in predators population after application of various compounds during 2010 and 2011 seasons

\begin{tabular}{|c|c|c|c|c|c|c|c|}
\hline \multirow[t]{3}{*}{ Treatment } & \multicolumn{6}{|c|}{ \% Reduction in predators population after indicated sprays } & \multirow{3}{*}{ Mean \pm SD } \\
\hline & \multicolumn{2}{|c|}{$1^{\text {st }}$ spray } & \multicolumn{2}{|c|}{$2^{\text {nd }}$ spray } & \multicolumn{2}{|c|}{$3^{\text {rd }}$ spray } & \\
\hline & 1 week & 2 weeks & 1 week & 2 weeks & 1 week & 2 weeks & \\
\hline Chloropyrifos & 42.55 & 65.38 & 66.67 & 80.00 & 57.14 & 73.91 & $64.28+5.1$ \\
\hline Alpha-cypermethrin & 49.52 & 85.58 & 100.00 & 100.00 & 63.17 & 87.77 & $81.00+2.68$ \\
\hline Chlorosan (M1) & 16.92 & 72.31 & 73.75 & 96.40 & 74.29 & 80.43 & $69.02 \pm 4.3$ \\
\hline Feroban $(\mathrm{M} 2)$ & 77.14 & 64.08 & 61.08 & 72.83 & 54.51 & 66.78 & $66.07+3.08$ \\
\hline Cygron (M3) & 63.56 & 81.78 & 73.68 & 84.21 & 77.44 & 79.41 & $76.68 \pm 3.08$ \\
\hline Engeo (M4) & 88.33 & 92.13 & 82.95 & 91.82 & 52.52 & 59.98 & $77.96 \pm 4.64$ \\
\hline
\end{tabular}

In conclusion, the new insecticides mixtures proved to be unprofitable in controlling cotton bollworms according to the results of the current study, where the average reduction percentages occurred in bollworms infestation for the tested insecticide mixtures were nearly the same compared to the conventional insecticides, alpha-cypermethrin and chloropyrifos. Also, all the tested compounds were very destructive to Chrysoperla carnea, Coccinella spp., Orius spp., Scymnus spp and true spiders.

\section{REFERENCES}

Abbas, M.S.T. and Y.A.A. El-Deeb, 1993. On the natural enemies of the major pests infesting cotton in Egypt. J. Agric. Res., 71(1): 131-137.

Abd El-Mageed, A.E.M. and S.E.M. Shalaby, 2011. Toxicity and biochemical impacts of some new insecticide mixtures on cotton leaf worm Spodoptera littoralis (Boisd.). J. Plant Protect. Sci., 47(4): 166 - 175.

Al-Beltagy, A.M.; A.M. Hamid and I.M. Galal, 1999. Population density and dynamics of some common predators under alternative pink bollworm control programs. $2^{\text {nd }}$ Int. Conf. Pest Cont., Mansoura, Egypt, (9): 105- 112.

Aydin, H. and M.O. Gürkan, 2006. The efficacy of spinosad on different strains of Spodoptera littoralis (Boisduval) (Lepidoptera: Noctuidae). Tur. J. Biol., 30: 5-9.

Bramhankar, S.A.; S.A. Nibalkar and Y.M. Taley, 1990. Potential of synthetic pyrethroids in alternation with conventionals in control of bollworms complex of cotton H.4. Indian J. Entomol., 52(3): 456-460.

Costat Program, 2006. Version 6.311, Cohort software Inc. Monterey http://www.cohort.com/download.costat.html.

El-Aswad, A.F., 2007. Efficiency of certain insecticides and insect growth regulators alone or in mixture with chloropyrifos for the integrated control of the Egyptian cotton leafworm. J. Pest Cont. \& Environ. Sci., 15(2): 2948.

El-Basyouni, S.A., 2003. Efficiency of some conventional insecticides on controlling the larvae of the bollworms. J. Agric. Sci., Mansoura Univ., 28(3): 363-368.
El-Dewy, M.E.H., 2006. Toxicological studies on some pests attacking cotton. Ph.D. Thesis, Kafr El-Sheikh Univ., Fac. Agric., Egypt. 332 pp.

El-Hamaky, M.A.; Y.A. El-Deeb and W.M. Watson, 1993. Efficiency of different chitin synthesis inhibitors and conventional insecticides applied singly and in binary mixtures against bollworms infesting cotton. J. Agric. Res. Tanta Univ., 19(3): 708-716.

El-Zahi, E.S. and S.A. Arif, 2011. Field evaluation of recommended insecticides to control bollworms on cotton aphid, Aphis gosypii Glover and their side effect on associated predators. J. Pest Cont. \& Environ. Sci., 19(1): 55-68.

Hafez, M., 1960. The effect of some new insecticides on predators of the cotton leafworm in cotton fields. Agric. Res. Rev. Cairo, 38(1): 147-179.

Haque, H., 1991. Imported generic pesticides need to be checked before marketing. Pak. Agric. Pest. Association Bull., 16-17.

Henderson, C.F. and E.W. Tilton, 1955. Tests with acaricides against the brown mite. J. Econ. Entomol., 48: 157-161.

Khan, R.R.; S. Ahmed; M.W. Saleem and M. Nadeem, 2007. Field evaluation of different insecticides against spotted bollworms Earias spp. at district Sahiwal. Pak. Entomol., 29(2): 129-133.

Khurana, A.D. and A.N. Verma, 1991. Bioefficacy of some synthetic pyrethroids and conventional insecticides against pink bollworms on cotton. Indian J. Agric. Res., 25(1): 27-32.

Kostandy, S.N., 1995. The simultaneous effect of early using of insecticides on cotton pests and its related natural enemies. Annals of Agric. Sci., Cairo, 40(2): 877-889.

Mushtaq, A., 2004. Potentiation/antagonism of deltamethrin and cypermethrin with organophosphate insecticides in the cotton bollworm, Helicoverpa armigera (Lepidoptera: Noctuidae). Pest. Biochem. \& Physiol., 80: 31-42.

Ravi, G. and S. Verma, 1997. Persistence and dissipation of insecticides against Heliothis armigera on chickpea. Indian J. Entomol., 59: 62-68.

Salama, A.E..; M.A. Salama; M.A. Abd-Elbaky; A.A. Ismail; M.G. Abas and S.A. Aref, 2006. Side effects of insecticidal treatments on six main predators commonly found in cotton fields. J. Agric. Sci. Mansoura Univ., 31(1): 429-439. 
Shaaban, A.M. and H.S. Radwan, 1974. Population dynamics of the pink bollworm, Pectinophora gossypiella (Saund.) in relation to blooming and fruiting curves of cotton plants. Pflkrankh, 4: 206-211.

Sharaf, F.H., 2003. Assessment the efficiency of certain different insecticides against both spiny and pink bollworms on cotton crop. J. Agric. Sci., Mansoura Univ., 28(3): 2369 - 2374.

Watson, W.M.; A.A. El-Dahan; F.A. Khalil and A. Soieb, 1981. Effectiveness of sequential use of insecticides on pink bollworm, Pectinophora gossypiella infestation. Proc. $4^{\text {th }}$ Arab Pesticide Conf. Tanta Univ., (IIIA): 95-104.
Younis, A.M.; H.H.S. Hamouda; A.S. Ebrahim and M.A.Z. Zeitoun, 2007. Field evaluation of certain pesticides against the cotton bollworms with special reference to their negative impact on beneficial arthropoda. $8^{\text {th }}$ African Crop Sci. Soc. Conf. Elminia, Egypt, 27-31 Oct., pp. 9331002.

Yousif-Khalil, S.I.; S.A. Raslan; O.I. Hegab and O.S. Abd Elsattar, 2008. Efficiency of spinosad and runner against pink bollworm and predators population on cotton fields. Zagazig J. Agric. Res., 35(2): 407-422.

Zidan, N.A.; J.B.A. El-Naggar; S.A. Aref and M.E.H. ElDewy, 2012. Field evaluation of different pesticides against cotton bollworms, sucking insects and their side effects. J. American Sci., 8(2): 128-136.

\section{الملخص العربي}

\section{تأثير بعض المخاليط الجديده للمبيدات الحشرية ضد ديدان اللوز وتأثيراتما الجحانبية على المفترسات}

\section{المصاحبة}

$$
\text { مديحة الصباحى حامد الديوى، الزاهى صابر الزاهى }
$$

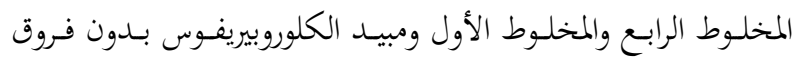

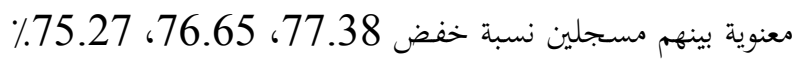

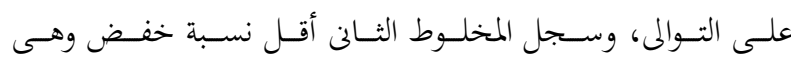

74.15٪. كانت النتائج في موسم نموالقطن 2011 تقريبا لها نفس

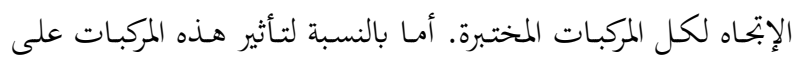

المفترسات المصاحبة في حقول القطن، فيمكن ترتيب المركبات تنازليا

حسب النسبة المئوية للخفض الحادث في تعداد المفترسات كما يلى:

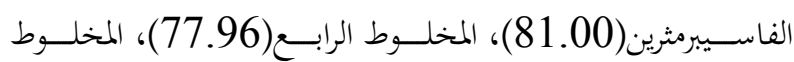

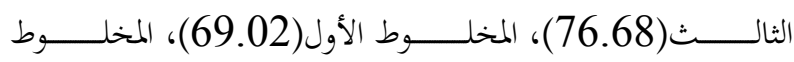

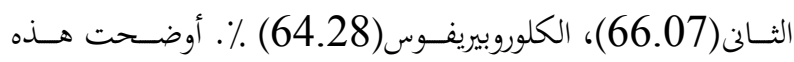

الدراسـة أن المخـاليط الجديـدة مسن المبيـات لم تثبـت ميـزات إضـافية

مقارنة بالمبيدات التقليدية في مكافحة ديدان اللوز حيث أها أعطت

تقريبا نفس الفاعلية ضد الآفة كما كانت ضارة بالمفترسات المصاحبة

وأيضا ربما تزيد المقاومة المشتركة للمبيدات بإستخدام هذه المخاليط.
أصسبحت مقاومـة ديــان اللـوز الشـوكية والقرنفليـة لفعـل معظم

المبيـات الحشـرية المسـجلة عائقـا في نجاح عمليـة المكافحـة بالمبيـات التقليديـة، لـذا تم إجـراء بجـارب حقليـة لدراسـة فعاليـة أربعـة خخـاليط حشــرية جديــدة وهــى كلوروبيريفــوس + ســيبرميثرين(مخلــوط 1)،

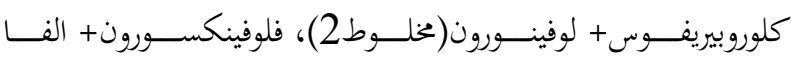
سيبرميثرين(مخلـوط3)، ثيو ميثوكسـام+ لامـدا سيهالوثرين(مخلـوط

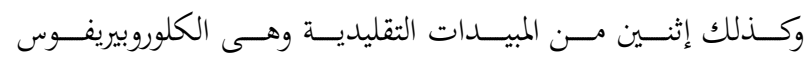

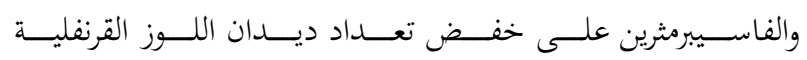
والشوكية Eectinophora gossypiella تم دراسـة تاثير هذه المـواد المختـبرة على بعض المفترسـات المصـاحبة. أوضسحت النتـائج المتحصل عليها فن موسم نمو القطن 2010م أن المخلوط الثالث والفاسيبرميثرين فن ثلاث رشات متتالية من كلاوما من أفضل المعاملات المختبرة حيث كانت نسبة الخفض في تعداد ديدان

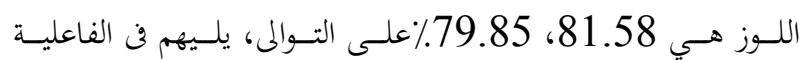

